U. S. Department of Energy Hydrogen Program

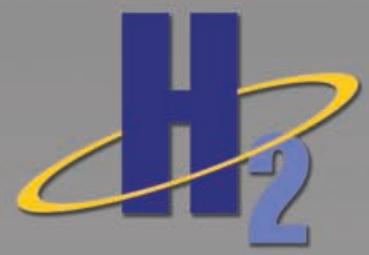

\title{
Fuel Cell System for Transportation - 2005 Cost Estimate
}

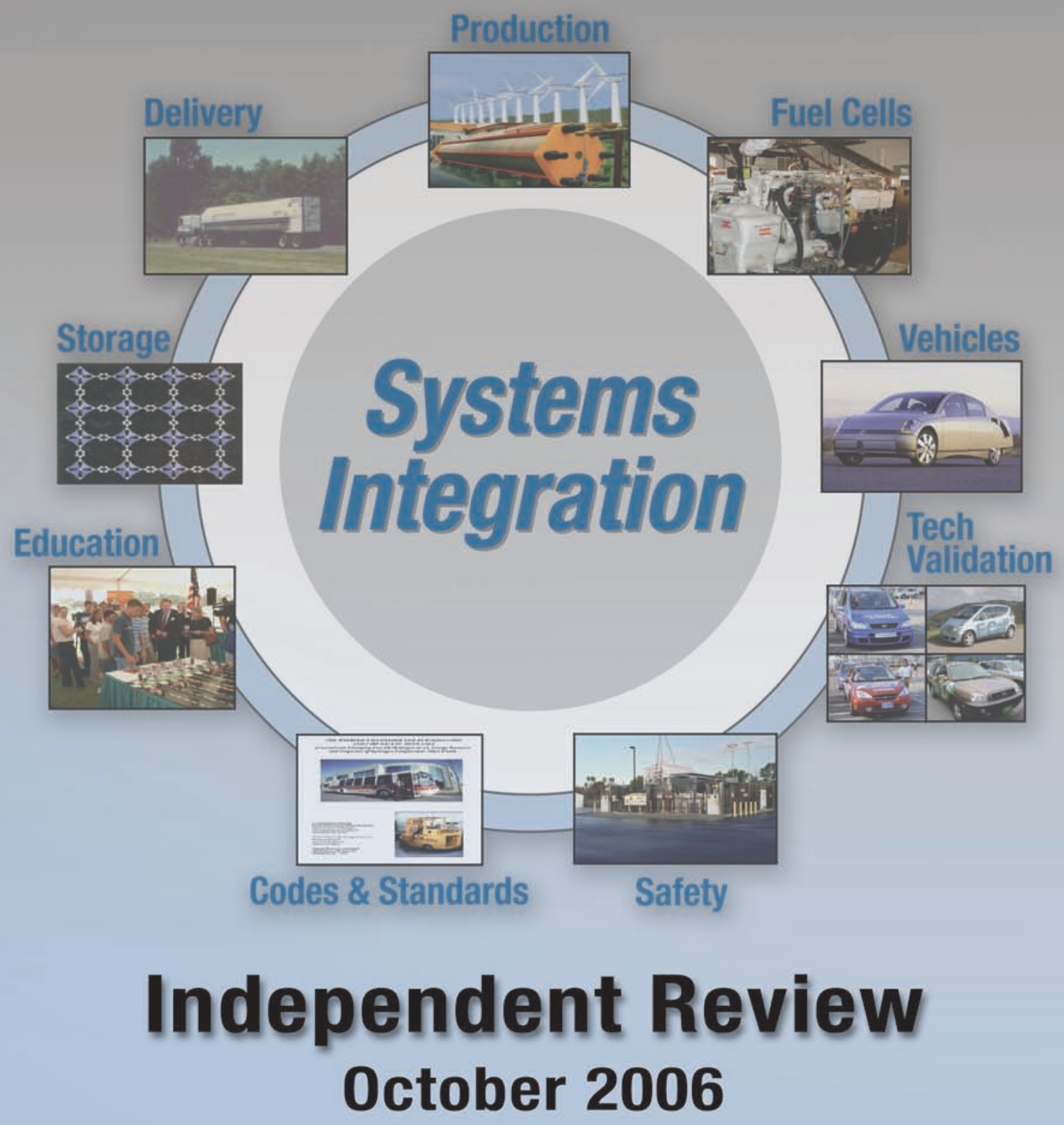

National Renewable Energy Laboratory 1617 Cole Boulevard Golden, Colorado 80401-3393 303-275-3000 • www.nrel.gov 


\section{NOTICE}

This report was prepared as an account of work sponsored by an agency of the United States government. Neither the United States government nor any agency thereof, nor any of their employees, makes any warranty, express or implied, or assumes any legal liability or responsibility for the accuracy, completeness, or usefulness of any information, apparatus, product, or process disclosed, or represents that its use would not infringe privately owned rights. Reference herein to any specific commercial product, process, or service by trade name, trademark, manufacturer, or otherwise does not necessarily constitute or imply its endorsement, recommendation, or favoring by the United States government or any agency thereof. The views and opinions of authors expressed herein do not necessarily state or reflect those of the United States government or any agency thereof.

Available electronically at http://www.osti.gov/bridge

Available for a processing fee to U.S. Department of Energy and its contractors, in paper, from:

U.S. Department of Energy

Office of Scientific and Technical Information

P.O. Box 62

Oak Ridge, TN 37831-0062

phone: 865.576 .8401

fax: 865.576 .5728

email: mailto:reports@adonis.osti.gov

Available for sale to the public, in paper, from:

U.S. Department of Commerce

National Technical Information Service

5285 Port Royal Road

Springfield, VA 22161

phone: 800.553 .6847

fax: 703.605.6900

email: orders@ntis.fedworld.gov

online ordering: http://www.ntis.gov/ordering.htm

This publication received minimal editorial review at NREL 


\section{Table of Contents}

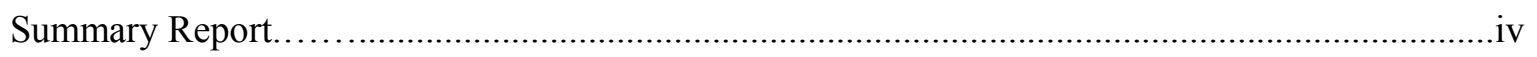

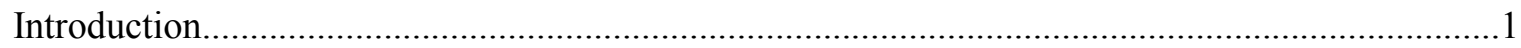

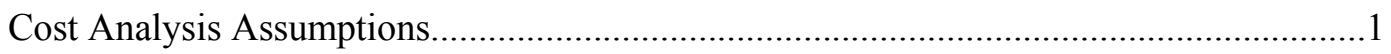

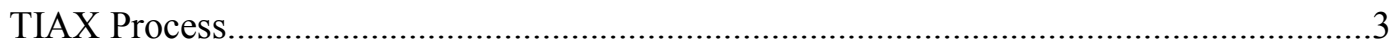

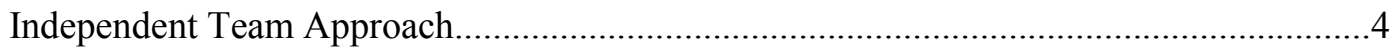

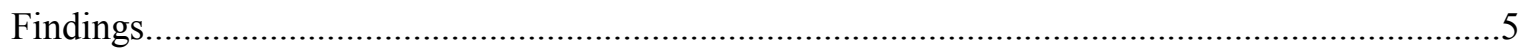

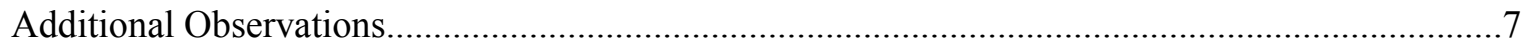

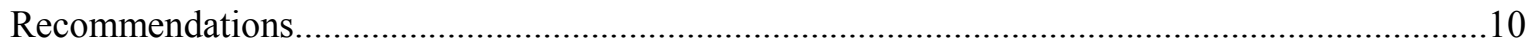

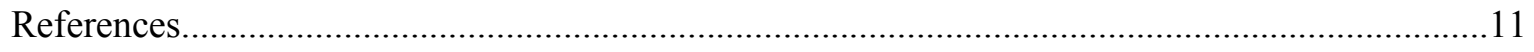

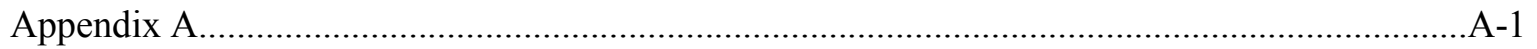

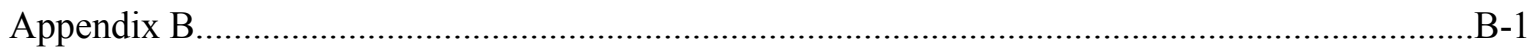




\section{INDEPENDENT REVIEW TEAM SUMMARY REPORT}

June 21, 2006

From: Independent Review Team, Fuel Cell System Cost for Transportation - 2005 Cost Estimate

To: Dale A. Gardner, NREL, DOE Hydrogen Systems Integrator

Subject: Independent Review Team Report

Per the tasks and criteria of the Independent Review Plan of February 17, 2006, this is the Independent Review Team's consensus technical conclusion, arrived at from data collection, review, interviews, and deliberations over the period February through May, 2006:

\section{Conclusion Statement:}

The Team found the methodology used by TIAX to estimate the cost of producing PEM fuel cells to be reasonable and, using 2005 cell stack technology and assuming production of 500,000 units per year, to have calculated a credible cost of $\$ 108 / \mathrm{kW}$.

\section{$\underline{\text { Rationale for Conclusion: }}$}

The Independent Review Team believes the process used by TIAX for the bottom-up determination of the cell stack costs yielded appropriate and representative results within the framework of the assumptions and recommendations from DOE and the FreedomCAR and Fuel Partnership Fuel Cell Technical Team.

In general, the fuel cell companies and the national laboratories interviewed agree with the results of the TIAX cost analysis, based on the assumptions of 2005 cell stack technology and 500,000 units per year. Fuel cell component manufacturers agreed only with the estimated cost of their specific components, since they did not have the knowledge to comment on the total PEM fuel cell system.

The TIAX cost analysis should not be used to infer that industry is prepared to manufacture 500,000 units per year based on the 2005 cell stack technology. Respondents stressed that the TIAX cost estimate of $\$ 108 / \mathrm{kW}$ is based on many design and manufacturing assumptions, including manufacture of 500,000 units, \$900/troy ounce platinum, 2005 cell stack technology, and vertical integration of the stack manufacturing process. No company is currently ready to produce either the cell stack or the balance-ofplant fuel cell components for 500,000 PEM fuel cell systems, let alone a complete fuel cell system at $\$ 108 / \mathrm{kW}$. Industry anticipates major investments would be required to achieve the production volumes necessary for transportation applications.

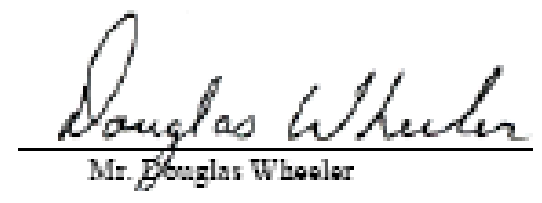




\section{Introduction}

The U.S. Department of Energy (DOE) Hydrogen, Fuel Cells and Infrastructure Technologies Program Manager asked the National Renewable Energy Laboratory (NREL) to commission an independent review of the 2005 TIAX cost analysis for fuel cell production. The NREL Systems Integrator is responsible for conducting independent reviews of progress toward meeting the DOE Hydrogen Program (the Program) technical targets. An important technical target of the Program is the proton exchange membrane (PEM) fuel cell cost in terms of dollars per kilowatt $(\$ / \mathrm{kW})$. The Program's Multi-Year Program Research, Development, and Demonstration Plan established $\$ 125 / \mathrm{kW}$ as the 2005 technical target.

Over the last several years, the Program has contracted with TIAX, LLC (TIAX) to produce estimates of the high volume cost of PEM fuel cell production for transportation use. Since no manufacturer is yet producing PEM fuel cells in the quantities needed for an initial hydrogen-based transportation economy, these estimates are necessary for DOE to gauge progress toward meeting its targets. For a PEM fuel cell system configuration developed by Argonne National Laboratory, TIAX estimated the total cost to be $\$ 108 / \mathrm{kW}$, based on assumptions of 500,000 units per year produced with 2005 cell stack technology, vertical integration of cell stack manufacturing, and balance-of-plant (BOP) components purchased from a supplier network. Furthermore, TIAX conducted a Monte Carlo analysis by varying ten key parameters over a wide range of values and estimated with $98 \%$ certainty that the mean PEM fuel cell system cost would be below DOE's 2005 target of $\$ 125 / \mathrm{kW}$.

NREL commissioned DJW TECHNOLOGY, LLC to form an Independent Review Team (the Team) of industry fuel cell experts and to evaluate the cost estimation process and the results reported by TIAX. The results of this independent review will permit NREL and DOE to better understand the credibility of the TIAX cost estimation process and to implement changes in future cost analyses, if necessary.

\section{Cost Analysis Assumptions}

DOE determined many of the top-level assumptions, in consultation with the FreedomCAR and Fuel Partnership Fuel Cell Technical Team (Tech Team), which were used by TIAX in its analysis. Lower level assumptions were developed by TIAX, as required, and are described herein when they are important to understanding the overall results.

Fuel Cell Configuration: DOE requested that TIAX analyze an 80-kWnet direct hydrogen PEM fuel cell system which includes the fuel cell stack and balance-of-plant (BOP) components for air, water, thermal, and fuel management, but not the hydrogen storage and power conditioning, since the latter are not included in DOE's $\$ 125 / \mathrm{kW}$ target. DOE provided TIAX access to a PEM fuel cell system configuration and model developed by Argonne National Laboratory (ANL). The ANL model provides the basis for specifying the overall system, subsystem, and component performance parameters and the fluid and electrical interfaces.

The TIAX cost analysis uses representative component designs, manufacturing processes for components, the development of a bill of materials, and list of purchased components. The model, data, component designs, and results were refined on the basis of recommendations from DOE, the Tech Team, and fuel cell system and component developers.

Figure 1 shows the major components of ANL's PEM fuel cell system configuration. The BOP subsystems include: 
1. The air delivery system with the compressor-expander supplying pressurized air to the enthalpy wheel. The enthalpy wheel humidifies the incoming air with moisture received from the exit gas of the cathode (air) side of the PEM stack. The cathode exit gas humidifies the incoming hydrogen through a membrane humidifier before high-humidity gas is delivered to the enthalpy wheel. Both the compressor-expander and enthalpy wheel are powered by electric motors. The compressor-expander pressurizes the incoming air to $\sim 2.5$ bar at peak power and $\sim 1.6$ bar at $25 \%$ of peak power.

2. The fuel delivery system has an ejector system for recirculation of the hydrogen when operating at the higher pressures. At low pressures an electric hydrogen recirculation pump is used. The hydrogen recirculation provides up to $99 \%$ hydrogen utilization. The membrane humidifier humidifies and preheats the incoming hydrogen. Purging of nitrogen crossing over through the PEM fuel cell membrane is required.

3. The thermal management system contains a coolant pump, a radiator, and a fan. The pump and fan are powered by an electric motor.

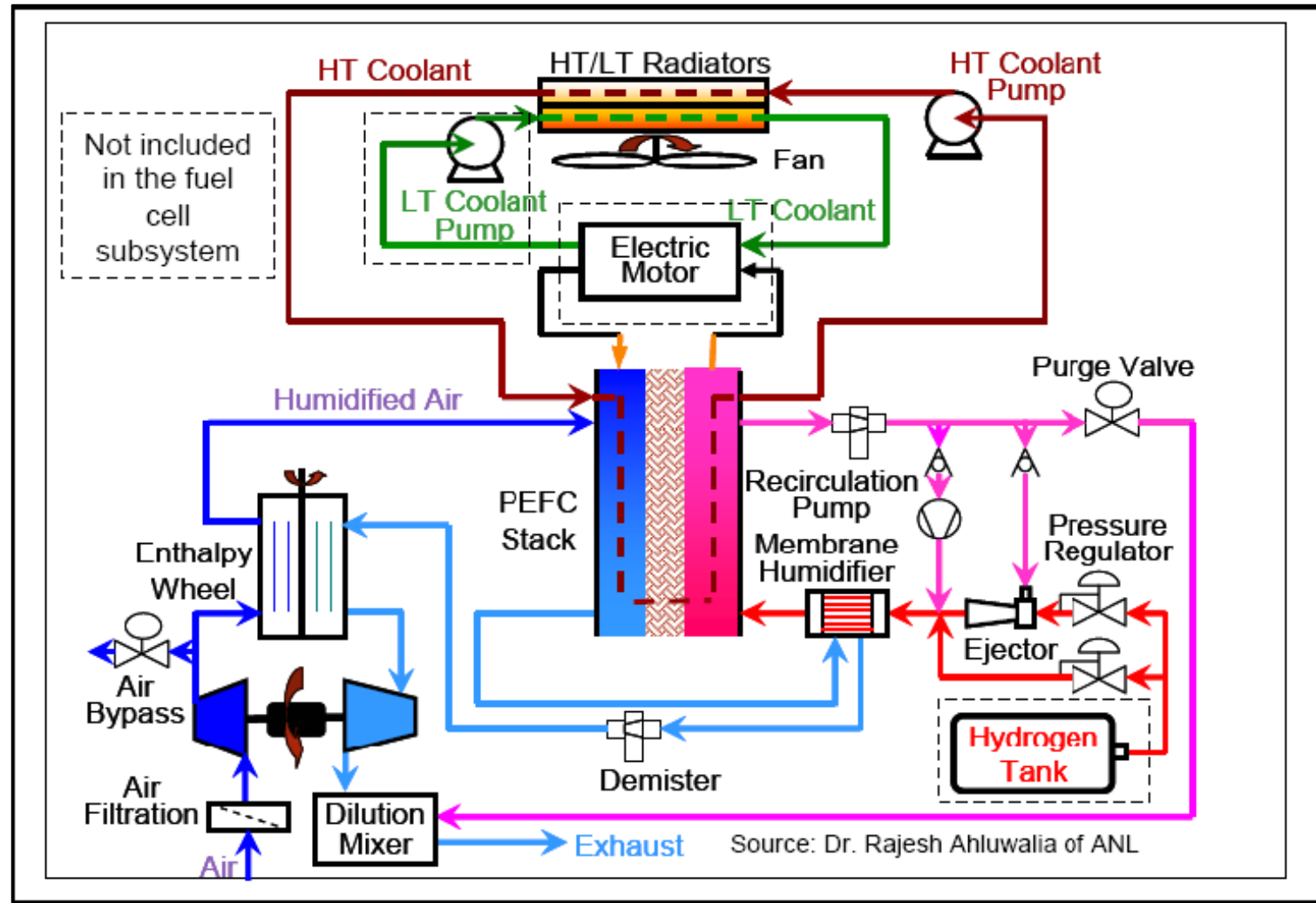

Figure 1: PEM Fuel Cell System Model developed by Argonne National Laboratory (Carlson et al. 2005)

Manufacturing Scale: In accordance with recommendations from DOE and the Tech Team, TIAX used current (2005) cell stack technology, assumed production of 500,000 PEM fuel cell systems (80 $\mathrm{kWnet}$ ) for automotive applications, and projected BOP technology.

Catalyst Loadings and Platinum Price: Loadings and price were set by DOE's Fuel Cell Team, with recommendations from the Tech Team, at $0.75 \mathrm{mg} \mathrm{Pt} / \mathrm{cm}^{2}$ and $\$ 900 /$ troy ounce (troz), respectively. 
System Integration: For ease of analysis, DOE directed that TIAX assume vertical integration of the stack manufacture, i.e., one company would manufacture the complete cell stack from ionomer, catalyst, and bipolar plate precursor material to build a complete cell stack. The TIAX cell stack analysis is a bottom-up approach using this vertical integration assumption.

\section{TIAX Process}

Stack costs were estimated by evaluating known manufacturing processes and assuming they could be adapted to manufacture fuel cell components. The BOP analysis is based on component costs provided by industry and benchmark checked by TIAX.

TIAX conducted both Monte Carlo (see Figure 2) and single variable sensitivity analyses on key parameters (see Table 1). The results indicate a baseline cost estimate of $\$ 108 / \mathrm{kW}$ and a $98 \%$ confidence that the cost would be less than DOE's 2005 target of $\$ 125 / \mathrm{kW}$.

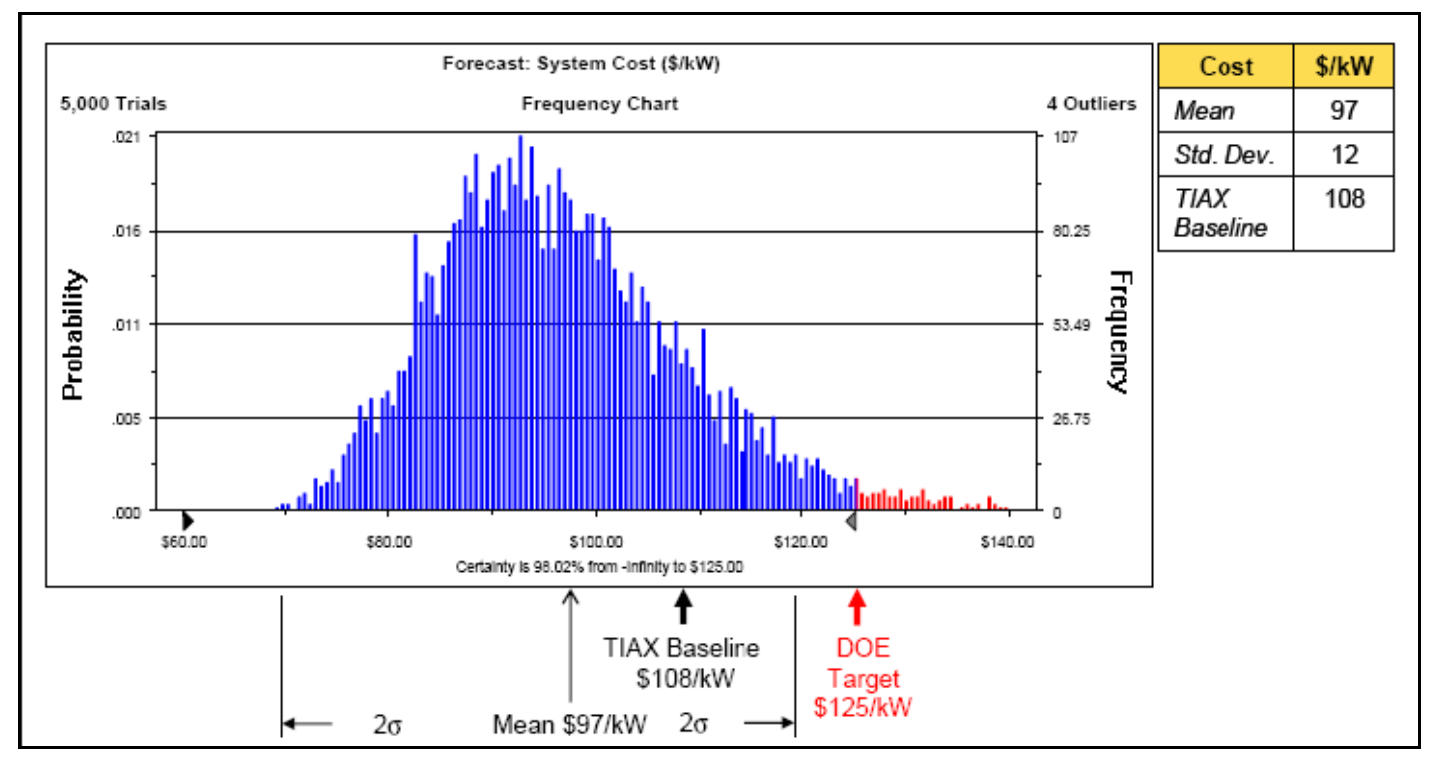

Figure 2: Results of Monte Carlo simulation for the variation of input parameters (Carlson et al. 2005)

\begin{tabular}{|l|l|c|c|c|}
\hline \multicolumn{1}{|c|}{ Parameter } & \multicolumn{1}{c|}{ Units } & Minimum & Baseline & Maximum \\
\hline Power density & $\mathrm{mW} / \mathrm{cm}^{2}$ & 350 & 600 & 800 \\
\hline Platinum cost & $\$ / \mathrm{troz}$ & 450 & 900 & 900 \\
\hline Pt loading & $\mathrm{mg} / \mathrm{cm}^{2}$ & 0.45 & 0.75 & 0.75 \\
\hline Nafion $\AA$ cost $(\$ / \mathrm{lb})$ & $\$ / \mathrm{kg}$ & 44 & 176 & 220 \\
\hline Graphite cost & $\$ / \mathrm{lb}$ & 1 & 2 & 4 \\
\hline Carbon cloth cost & $\$ / \mathrm{kg}$ & 15 & 30 & 60 \\
\hline Nitrile rubber cost & $\$ / \mathrm{lb}$ & 3 & 5 & 8 \\
\hline Compressor-expander cost & \$/unit & 700 & 1080 & 1200 \\
\hline $\mathrm{H}_{2}$ blower cost & $\$ / \mathrm{unit}$ & 200 & 300 & 500 \\
\hline Radiator cost & \$/unit & 183 & 220 & 260 \\
\hline
\end{tabular}

Table 1. Parameter Values for the System Cost Sensitivity Analysis Parameter Units Minimum Baseline Maximum 


\section{Independent Review Team Approach}

NREL commissioned DJW TECHNOLOGY, LLC (DJWT) to conduct this independent review. DJWT assembled an Independent Review Team (the Team) of four industry experts with more than 80 years combined experience in fuel cell research, development, and manufacturing. Backgrounds of Team members are provided in Appendix A.

The Team assessed the TIAX cost analysis (Carlson et al. 2005), developed discussion points and questions, and conducted interviews with 19 companies and three national laboratories that are all active in PEM fuel cell development, plus TIAX analysis staff. These companies represented fuel cell integrators, fuel cell stack component manufacturers, and BOP manufacturers (see Appendix B).

The FreedomCAR and Fuel Partnership Fuel Cell Technical Team and the DOE Fuel Cell team were also interviewed. General Motors, DaimlerChrysler, and Ford are members of the Tech Team and participated in the review as part of that team. In addition, General Motors, DaimlerChrysler, and Ford were individually contacted after the formal independent review period (due to schedules of key personnel in those companies). Their inputs were consistent with those received from other parties and would not have materially changed the results presented in this report.

The following ground rules were established for the industry and national laboratory interviews:

1. The company or national laboratory would be identified.

2. Responses to the questions and summary remarks would not be attributed to any specific company or national laboratory.

3. No intellectual property was to be disclosed.

4. Follow-up would be provided, as requested, to the companies and national laboratories. 


\section{Findings}

The findings of the Team are the results of interviews with industry and three national laboratories, and an evaluation of the DOE-directed TIAX cost analysis, including input from the TIAX cost analysis group members.

\section{The fuel cell industry agrees with the methodology used in the TIAX cost analysis.}

The Team found the methodology used by TIAX to estimate the cost of producing PEM fuel cells to be reasonable and, using 2005 cell stack technology and assuming production of 500,000 units per year, to have calculated a credible cost of $\$ 108 / \mathrm{kW}$. Fuel cell component manufacturers and fuel cell integrators generally agree with the PEM fuel cell system cost range of $\$ 108-\$ 125 / \mathrm{kW}$, based on the assumptions used in the TIAX report. Many of the companies interviewed did not have the knowledge to comment on the cost of the entire system, but were comfortable commenting on the cost of components with which they were directly involved.

Vertical integration of the stack manufacture (i.e., one company would manufacture the complete cell stack from ionomer, catalyst, and bipolar plate precursor material to build a complete cell stack) is not the model envisioned by the companies interviewed. Even so, they agreed that TIAX established a reasonable cost number - within the boundaries of the assumptions - that can be used to gauge progress in the development and eventual commercialization of fuel cells.

Interviewees believed the BOP costs for the fuel cell power plant were consistent with their understanding; however, they expressed concerns that the specific system or BOP components differed from their experience and that their final power plant designs for commercial production would be different from the ANL model used by TIAX. They also expressed caveats concerning the possible BOP cost increases to accommodate application issues such as:

- Cold start

- Durability - reliability of BOP components with moving parts (enthalpy wheel) and humidification approach

- Operability - transient response, hot day operation, hill climbing, air conditioning.

The TIAX cost analysis should not be used to infer that industry is prepared to manufacture 500,000 units per year based on the 2005 cell stack technology. Respondents stressed that the TIAX cost estimate of $\$ 108 / \mathrm{kW}$ is based on many design and manufacturing assumptions, including manufacture of 500,000 units, $\$ 900 /$ troz Pt, 2005 cell stack technology, and vertical integration of the stack manufacturing process. No company is currently ready to produce either cell stack or BOP components for 500,000 PEM fuel cell systems, let alone a complete fuel cell system at $\$ 108 / \mathrm{kW}$. Industry identified the need for manufacturing $R \& D$, and anticipates major investments would be required to achieve the production volumes necessary for transportation applications.

\section{The bottom-up process used by TIAX for estimating cell stack cost is valid.}

The Team believes the process used by TIAX for the bottom-up determination of the cell stack yielded appropriate and representative results within the framework of the assumptions and recommendations from DOE. The BOP cost analysis was based on supplier input and the requirements were established by the ANL model. The supplier input contributed to cost projections by TIAX, which were then calibrated against TIAX's experience with similar technologies. There is confidence in this approach within the assumptions and recommendations from DOE and ANL. 


\section{The PEM fuel cell system model performance was close to state-of-the-art.}

The Team believes that the performance of the PEM fuel cell system model was close to the state-ofthe-art for the cell stack. The purpose of the ANL model is to represent a generic fuel cell system that could achieve the performance targets set by DOE. In particular, efficiency at rated power is targeted by DOE at $50 \%$ and efficiency at $25 \%$ of rated power is targeted at $60 \%$. At rated power, the ANL model achieves $47 \%$ efficiency and at $25 \%$ of rated power, $55 \%$ efficiency.

Some BOP components have not been fully demonstrated. Industry reported to the Team that the compressor-expander was based on data from separate devices and the combined device had not been demonstrated. The enthalpy wheel was considered bulky and its ultimate reliability was questioned. Discussions with industry identified alternative technologies that would replace the compressorexpander and possibly the enthalpy wheel.

Predictably, the ANL model was accepted by some of the fuel cell manufacturers, but not by all. Fuel cell integrators have their own fuel cell system designs based on their proprietary technologies. The configuration of the fuel cell system has a strong influence on the cost analysis, since it will influence the component performance specifications (e.g., inlet and outlet pressures, temperatures, flow-rates, and compositions) and establishes the BOP components. The ANL model may be too focused on one PEM system or one BOP component manufacturer. Industry representatives suggested alternative system designs and recommended that a study be undertaken to identify the optimum system for PEM fuel cells.

\section{Some cost factors may have been underestimated.}

Assembly of the cell stack was not addressed with the same detail as the fuel cell stack components. The TIAX approach assumes a robotic pick-and-place function that would rapidly assemble the stack. Further details on the rate of stack assembly (e.g., time to assemble a stack), the number of assembly lines, and the capital investment for these lines are needed to support the assembly costs. Careful attention to stack assembly is critical to achieving a high acceptance rate and low assembly cost. Industry recommends future DOE supported cost analyses address this issue.

Industry recognizes that quality control and stack conditioning could contribute significantly to cost but were excluded from the TIAX analysis at the recommendation of DOE and the Tech Team. Industry believes quality control is critical and potentially costly to develop and implement into the manufacturing process. TIAX states that quality control and stack conditioning could add $5 \%-50 \%$ to the cost. Narrowing this range will require additional analysis. Stack conditioning is addressed briefly in the TIAX report, indicating that a two-hour conditioning of the cell stack would cause a $2.5 \%$ increase in cell stack cost, whereas a 24 -hour conditioning would cause $\sim 33 \%$ increase.

\section{Industry recommends incremental production cost analysis.}

The cost analysis for the production of 500,000 PEM fuel cell systems provides a gauge by which DOE can evaluate the progress toward achieving the cost targets for automotive PEM fuel cells and, thus, is valuable. However, fuel cell companies believe progress will be made in incremental steps with several go/no-go decisions along the way. A real target that industry does consider viable is manufacturing 10,000 PEM fuel cell systems per year. Incremental increases from 10,000 to 100,000 PEM fuel cell systems are the targets for cost analysis that industry believes will be viable. 


\section{Additional Observations}

In general, the fuel cell companies and the national laboratories interviewed agree with the results of the TIAX cost analysis, given the assumptions provided by DOE and the Tech Team. However, as a result of extensive discussions with each of the interviewees, the Independent Review Team was able to recognize (1) opportunities for future reductions in PEM fuel cell system cost as well as (2) items that could represent additional cost risk. Many of these areas are already the topics of DOE analysis and $\mathrm{R} \& \mathrm{D}$.

\section{Potential Opportunities for Future Cost Reductions}

1. Platinum. The DOE assumption going into the analysis provided a cost range of $\$ 450-\$ 900 /$ troz for platinum. The price of platinum at the time of this review was in excess of $\$ 1,200 /$ troz, and industry inputs suggest it may never return to $\$ 450 /$ troz. However, there may be ways to limit catalyst costs:

\section{a. Platinum content can be reduced.}

The platinum companies stated that current platinum reserves are sufficient for the production of 500,000 PEM fuel cell systems per year. However, it would take one to two years to deliver the catalyst because production facilities are not available. Reducing the platinum content would reduce the cost of the PEM fuel cell system. Two respondents stated that platinum reductions of $50 \%$ from the baseline of $0.75 \mathrm{mg} / \mathrm{cm}_{2}$ had already been achieved in laboratory testing and that the durability and power density remained constant.

With platinum content reductions and $\$ 900 /$ troz, the estimated PEM fuel cell system cost could be reduced from $\$ 108$ to $\$ 83 / \mathrm{kW}$. Extensive cell stack testing is needed to confirm these results, and the Team recommends testing at a neutral test facility.

\section{b. End users could own the platinum.}

In the supply chain scenario for cell stack manufacturing, markup is applied at each stage of manufacturing. Applying markup to the high cost catalyst at each stage would increase the cost of the PEM fuel cell system. An industry suggestion is that the end producer owns the platinum and subcontracts fabrication of the catalyst, the membrane electrode assemblies (MEAs) and eventually incorporates them into stacks. End user ownership of the platinum would eliminate markup on platinum and effectively transfer the risk of platinum ownership to the fuel cell integrator or automobile manufacturer at the end of the supply chain.

\section{c. Platinum should be recycled.}

Many industry respondents considered the life cycle of the platinum to be an important issue, especially the possibility of recycling platinum. Recovery at levels approaching $90 \%$ is needed to combat the high cost of platinum. This topic was not addressed in the TIAX report. Recycled platinum is considered by many industry interviewees to be the only path for PEM fuel cells with platinum catalysts. 


\section{d. Platinum might be profitably leased.}

Leasing of platinum was also brought up by industry. The manufacture of 500,000 PEM fuel cell stacks would consume approximately 2 million troz of platinum while worldwide demand for platinum was 6.7 million troz in 2005 (Platinum Today 2005). Some fuel cell companies responded that the automobile original equipment manufacturers (OEMs) should lease the platinum (inside the cell stack) to the vehicle purchaser.

\section{Bipolar plates can be thinner.}

The TIAX cost analysis states that compression-molded, graphite-resin composite plates may have thickness and conductivity limitations (Carlson et al. 2005). TIAX changed its analysis from the 2004 graphite resin composite formulation to an analysis of molded/stamped-expanded graphite foil to achieve thinner bipolar plates. A manufacturer of this type of bipolar plates disagreed with the thickness and conductivity statements of the analysis. Graphite foil also has high electrical conductivity, low contact resistance, and low specific density, and it can be manufactured in a roll-toroll continuous process with embossed compression molding.

Manufacturers of both types of plates reported that thinner plates can be made. The limit on bipolar plate thickness is based on two factors: (1) permeability of reactants through the web of the bipolar plate and (2) the flow field depths required to ensure the reactants are adequately distributed.

\section{High power densities may be achievable.}

The Team was told by MEA manufacturers that power densities are achievable at greater than the 600 $\mathrm{mW} / \mathrm{cm}^{2}$ baseline used in the analysis. Power densities of $700-1,000 \mathrm{~mW} / \mathrm{cm}^{2}$ have been obtained in laboratory tests. The full details were not revealed; however, the industry claims suggest cell stack cost reductions similar to those achieved in moving from $350 \mathrm{~mW} / \mathrm{cm}^{2}$ in 2004 to $600 \mathrm{~mW} / \mathrm{cm}^{2}$ in the 2005 baseline cost analysis. Further demonstration in cell stacks is needed before reduced costs can be claimed based on these data.

\section{Membrane electrode assembly technology is advancing.}

MEA manufacturers reported progress in roll processing of three-layer systems and advances toward five-layer systems. At least one manufacturer reported their three-layer, roll-to-roll process is already high volume. Some manufacturers indicated manufacturing development programs to adapt roll processing for fuel cell production would be costly, but they were moving forward. These continued efforts should be encouraged and may drive down costs. Industry anticipates a nonrecurring engineering investment in the transition from three-layer (catalyst coated membrane) structures to five-layer, and possibly seven-layer structures. The application of seals in the roll processing was considered a nontrivial manufacturing problem that would require process development.

\section{$\underline{\text { Additional Cost Risk Areas }}$}

\section{The lower range of the ionomer cost is questionable.}

A Stanford Research Institute (SRI) report (SRI 1983) reviewed ionomer costs and proposed the product value for ionomer was $\$ 60-\$ 89 / \mathrm{lb}$ for a $100,000-400,000 \mathrm{lb} / \mathrm{yr}$ (180 metric tons/year) facility. These values (in 1983 dollars) are associated with the capital investment and production cost for the ionomer and they compare well with the cost given in Table 19 (Carlson et al., 2005). 
However, given that energy costs have increased significantly since 1983, the SRI values are probably low.

The TIAX sensitivity analysis assumed a Nafion cost range from $\$ 20-\$ 100 / \mathrm{lb}$ with a most likely value of $\$ 80 / \mathrm{lb}$ (see Table 20 of Carlson et al. 2005) that is inconsistent with the SRI study. The low cost in Table 20 is attributed to the work of Gebert et al 2004. The membrane companies indicated the low-end cost may approach $\$ 90 / \mathrm{lb}$, in closer alignment with the SRI report.

\section{The woven gas diffusion layer is nonstandard.}

The gas diffusion layer (GDL) identified in the TIAX report is a woven material (Carlson et al. 2005). Although the cost difference is not very significant, non-woven GDLs are used by all but one of the MEA and cell manufacturers interviewed. The choice of woven GDLs is a cost risk that does not reflect industry or national laboratory views.

\section{Vertical integration of cell stack manufacturing is not supported by industry.}

Industry consensus was that no one company had all the technology or could afford to have all the technology to achieve vertical integration. The Independent Team concurs. The TIAX analysis did evaluate the value chain cost and included 30\% markup for the catalyst. Eliminating the catalyst markup and using the end user approach identified here will reduce the supply chain cost.

\section{Nonrecurring engineering costs are not included in the analysis.}

The analysis does not include nonrecurring costs for manufacturing. Nonrecurring manufacturing engineering costs need to be recovered by companies through sales revenue. Industry participants indicated that the high cost of transitioning from limited production $(<1,000$ fuel cell units/year) to automotive scale production (500,000 or more fuel cell units/year) will require a large investment in nonrecurring engineering. These costs would be in addition to the capital expenditures identified by TIAX for moving to automotive scale production. 


\section{Recommendations}

As a result of this comprehensive review, the Team prepared the following recommendations for future cost analyses of PEM fuel cell systems.

\section{Reduce platinum costs through recycling and alternative purchase options.}

Recycled platinum should be evaluated in future cost analyses. A general recommendation is for the DOE to increase its development programs on recycled platinum. A review of alternative methods of purchasing platinum is also recommended and should include purchase by the end user to minimize markup of the platinum during processing. An evaluation of the benefits of leasing platinum by the OEM or automobile manufacturers is also recommended.

\section{Quantify the cost of ionomer used in PEM membranes.}

The minimum cost of $\$ 20 / \mathrm{lb}$ for ionomer assumed by TIAX in its sensitivity analysis is not consistent with the available information. Industry input was closer to $\$ 90 / \mathrm{lb}$. A new evaluation of the cost of ionomer is recommended.

\section{Develop a value chain analysis of the cell stack.}

Value chain analysis of the cell stack should be used in all future cost analyses. The manufacturing concept of vertical integration for the cell stack should be reconsidered.

\section{Review the use of non-woven gas diffusion layers.}

Since non-woven GDLs are used by most MEA and cell manufacturers, they should be considered in all future cost analyses.

\section{Baseline design of the PEM fuel cell system should have broader input from industry.}

The PEM fuel cell system design should be reconsidered. Industry suggested alternative system designs and a study to identify the optimum system for PEM fuel cells. Any future models should be developed with broader industry and national laboratory input.

\section{Include nonrecurring engineering costs in future cost analyses.}

Nonrecurring manufacturing engineering costs need to be recovered by companies through sales revenue, and thus should be included in future cost analyses.

\section{Evaluate incremental production costs.}

Future cost analyses should address incremental production increases beginning with 10,000 units per year, in addition to the baseline of 500,000 units per year.

\section{Clarify intended usage of the cost analysis report.}

To avoid misinterpretation, future cost analyses should provide a statement in the front of the report that clearly identifies how the report should be used and not used. What can and, more importantly, what cannot be inferred from the results of the analysis should be clearly defined.

\section{Include more detail in future analyses.}

Future analyses would provide a greater understanding of the PEM costs if there were more detail provided in the bottom-up analysis. 


\section{References}

Carlson, E.;Kopf, P.; Sinha, J.; Sriramulu, S.; and Yang, Y. 2005. Cost Analysis of PEM Fuel Cell Systems for Transportation, Subcontract Report NREL/SR-560-39104. Golden, CO: National Renewable Energy Laboratory.

Gebert, M.; Hohlein, B. et al. Nov. 2004. "Benchmark Cost Analysis of Main PEFC-Ionomer Membrane Solutions," Trans. of the ASME, Journal of Fuel Cell Science and Technology, Vol. 1, pp. $56-60$.

Platinum Today (2005). www.platinum.matthey.com/market data/1147696728.html. SRI 1983. PEP (PROCESS Economic Program) \#166 Fluoropolymers. 


\section{Appendix A}

\section{Independent Review Team}

The National Renewable Energy Laboratory contracted with DJW TECHNOLOGY, LLC (DJWT) to conduct the independent review. An Independent Review Team of four industry experts with a combined experience of over 80 years in fuel cell research, development and manufacturing was assembled by DJWT.

DJW TECHNOLOGY, LLC: DJWT is a sole proprietorship formed by Douglas Wheeler to provide consulting services to industry, the national laboratories, and government agencies. Mr. Wheeler was manager technology and government contracts at UTC Fuel Cells (now UTC Power) for 18 years. At UTC Fuel Cells, he managed the Advanced Technology team during UTC Fuel Cells' transition from Phosphoric Acid fuel cells to PEM fuel cells. During this time period UTC Fuel Cells' critical atmospheric pressure technology for PEM fuel cells was developed. The Advanced Technology team developed and demonstrated the technology concepts for UTC Fuel Cells' automotive PEM fuel cell systems.

PEM ENGINEERS: PEM ENGINEERS was formed by David Watkins and Clarence Chow, two former long-term directors of Ballard's Advanced Systems and Transportation Programs.

David Watkins: During his 19 years at Ballard Power Systems, Mr. Watkins pioneered the PEM fuel cell technologies behind Ballard's emergence as a global industry leader, including an order of magnitude increase in power density, practical operation on air rather than on pure oxygen, operation on widely available hydrocarbon fuels rather than pure hydrogen, and the first methanol-to-electricity and natural gas-to-electricity integrated fuel power plants using PEM technology. He started Systems Engineering at Ballard in 1991, retired in 2002 as Director, Advanced Systems responsible for portable, stationary and transportation power plants.

Clarence Chow: Mr. Chow has extensive experience in fuel cell product development, particularly for automotive applications. During his 12 years at Ballard Power Systems, he held the positions as Stack Engineering Manager, Director of Transportation Programs and Director of Advanced Development. He managed a number of key projects that helped to put Ballard at the forefront of fuel cell product development for automobiles. He led the stack development that advanced the power densities to the needs of the automotive fuel cell systems and improved performance compatibility, reduced costs, and transformed the design for high volume production processes.

Paul J. Farris Consultant: Paul Farris has over 30 years experience in the fuel cell industry at UT Fuel Cells where he was Manager of Business Development. He was a key member of the PC 25 commercialization team and conducted cost and manufacturing analyses for the phosphoric acid fuel cell. He led the effort for UTC Fuel Cells on the commercialization of an on-sit hydrogen generations unit. He was instrumental in the UTC Fuel Cells' transition to PEM fuel cell for transportation applications and was an instructor at the Fuel Cell Short Course, "The Integrated System Approach to Fuel Cell Power Plant System Design" at the 2005 Fuel Cell Seminar. 


\title{
Appendix B
}

\section{Interviews for Independent Review of TIAX Cost Analysis Companies \& National Laboratories Interviewed}

\author{
Companies \\ - TIAX, LLC \\ - UTC Power, LLC \\ - SGL Carbon Group \\ - Porvair Advanced Materials \\ - 3M Company \\ - W. L. Gore \& Associates \\ - Ballard Power Systems \\ - Honeywell International Inc. \\ - Plug Power Inc. \\ - Arkema Group \\ - E-TEK Division of PEMAS Fuel Cell Technologies \\ - Directed Technologies, Inc (written response) \\ - DuPont E I DE NEMOURS \& CO, DuPont Fuel Cells \\ - GrafTech Advanced Energy Technology Inc. \\ - Parker Hannifin Corporation \\ - Dana Corporation \\ - Johnson Matthey \\ - Delphi Corporation (written response) \\ - Hydrogenics Corporation \\ - General Motors \\ - Daimler Chrysler \\ - Ford
}

\section{National Laboratories}

- Argonne National Laboratory

- National Renewable Energy Laboratory

- Los Alamos National Laboratory 


\section{REPORT DOCUMENTATION PAGE}

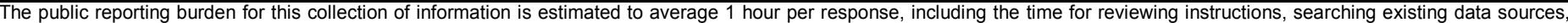

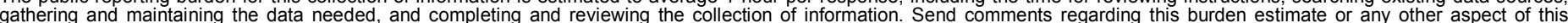

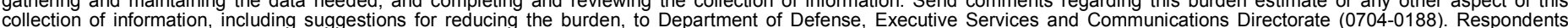

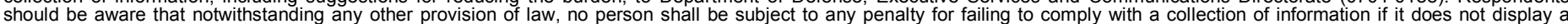

should be aware that notwithstanding

PLEASE DO NOT RETURN YOUR FORM TO THE ABOVE ORGANIZATION.

\begin{tabular}{l|l|l|} 
1. REPORT DATE $(D D-M M-Y Y Y Y)$ & 2. REPORT TYPE & 3. DATES COVERED (FrOm - TO)
\end{tabular}

October 2006

Independent Review Report

4. TITLE AND SUBTITLE

Fuel Cell System for Transportation - 2005 Cost Estimate

5a. CONTRACT NUMBER

DE-AC36-99-G010337

5b. GRANT NUMBER

5c. PROGRAM ELEMENT NUMBER

6. AUTHOR(S)

Douglas Wheeler

5d. PROJECT NUMBER

NREL/BK-150-40160

5e. TASK NUMBER

HS061002

5f. WORK UNIT NUMBER

7. PERFORMING ORGANIZATION NAME(S) AND ADDRESS(ES)

Douglas Wheeler

Independent Review Panel

8. PERFORMING ORGANIZATION REPORT NUMBER

LDC-6-66262-01

9. SPONSORING/MONITORING AGENCY NAME(S) AND ADDRESS(ES)

National Renewable Energy Laboratory

1617 Cole Blvd.

Golden, CO 80401-3393

10. SPONSOR/MONITOR'S ACRONYM(S)

NREL

11. SPONSORING/MONITORING AGENCY REPORT NUMBER NREL/BK-150-40160

12. DISTRIBUTION AVAILABILITY STATEMENT

National Technical Information Service

U.S. Department of Commerce

5285 Port Royal Road

Springfield, VA 22161

13. SUPPLEMENTARY NOTES

NREL Technical Monitor: Michael Duffy

14. ABSTRACT (Maximum 200 Words)

Independent review report of the methodology used by TIAX to estimate the cost of producing PEM fuel cells using 2005 cell stack technology.

\section{SUBJECT TERMS}

independent review; TIAX; cost analysis; fuel cells; cell stack

16. SECURITY CLASSIFICATION OF:
\begin{tabular}{|l|l|l|}
\hline a. REPORT & b. ABSTRACT & c. THIS PAGE \\
Unclassified & Unclassified & Unclassified \\
& & \\
\hline
\end{tabular}

\begin{tabular}{l|l} 
17. LIMITATION & 18. $\begin{array}{l}\text { NUMBER } \\
\text { OF ABSTRACT } \\
\text { OF PAGES }\end{array}$ \\
UL & \\
\end{tabular}

19a. NAME OF RESPONSIBLE PERSON

19b. TELEPHONE NUMBER (Include area code) 